\title{
Basic science (October 2005)
}

1. Aggarwal BB, Shishodia S, Takada $Y$, Banerjee S, Newman RA, Bueso-Ramos CE, Price JE. Curcumin suppresses the paclitaxelinduced nuclear factor-kappa B pathway in breast cancer cells and inhibits lung metastasis of human breast cancer in nude mice. Clin Cancer Res 2005; 11: 7490-7498.

2. Bowen TJ, Yakushiji H, Montagna C, Jain S, Ried T, Wynshaw-Boris A. Atm heterozygosity cooperates with loss of Brca1 to increase the severity of mammary gland cancer and reduce ductal branching. Cancer Res 2005; 65: 8736-8746.

3. Boyd NF, Rommens JM, Vogt K, Lee V, Hopper JL, Yaffe MJ, Paterson AD. Mammographic breast density as an intermediate phenotype for breast cancer. Lancet Oncol 2005; 6: 798-808.

4. Brenton JD, Carey LA, Ahmed AA, Caldas C. Molecular classification and molecular forecasting of breast cancer: Ready for clinical application? J Clin Oncol 2005; 23: 7350-7360.

5. Canzian F, McKay JD, Cleveland RJ, Dossus L, Biessy C, Boillot C, Rinaldi S, Llewellyn M, Chajes V, Clavel-Chapelon F, Tehard B, Chang-Claude J, Linseisen J, Lahmann PH, Pischon T, Trichopoulos D, Trichopoulou A, Zilis D, Palli $D$, Tumino $R$, Vineis $P$, Berrino $F$, Bueno-de-Mesquita HB, van Gils $\mathrm{CH}$, Peeters PHM, Pera G, Barricarte A, Chirlaque MD, Quiros JR, Larranaga N, Martinez-Garcia C, Allen NE, Key TJ, Bingham SA, Khaw KT, Slimani N, Norat T, Riboli E, Kaaks R. Genetic variation in the growth hormone synthesis pathway in relation to circulating insulin-like growth factor-I, insulin-like growth factor binding protein-3, and breast cancer risk: Results from the European prospective investigation into cancer and nutrition study. Cancer Epidemiol Biomar Prevent 2005; 14: 2316-2325.

6. Chen JQ, Yager JD, Russo J. Regulation of mitochondrial respiratory chain structure and

First published online 22/03/06

BCO/550/2005/JW function by estrogens/estrogen receptors and potential physiological/pathophysiological implications. BiochimEt Biophys Acta Mol Cell Res 2005; 1746: 1-17.

7. Chen WY, Bertone-Johnson ER, Hunter DJ, Willett WC, Hankinson SE. Associations between Polymorphisms in the vitamin $D$ receptor and breast cancer risk. Cancer Epidemiol Biomar Prevent 2005; 14: 2335-2339.

8. Chen ZT, Varney ML, Backora MW, Cowan K, Solheim JC, Talmadge JE, Singh RK. Downregulation of vascular endothelial cell growth factor-C expression using small interfering RNA vectors in mammary tumors inhibits tumor lymphangiogenesis and spontaneous metastasis and enhances survival. Cancer Res 2005; 65: 9004-9011.

9. Cheng CK, Chow LWC, Loo WTY, Chan TK, Chan V. The cell cycle checkpoint gene Rad9 is a novel oncogene activated by $11 \mathrm{q} 13$ amplification and DNA methylation in breast cancer. Cancer Res 2005; 65: 8646-8654.

10. Cui XJ, Schiff R, Arpino G, Osborne CK, Lee AV. Biology of progesterone receptor loss in breast cancer and its implications for endocrine therapy. J Clin Oncol 2005; 23: 7721-7735.

11. Debniak T, Gorski B, Huzarski T, Byrski T, Cybulski C, Mackiewicz A, GozdeckaGrodecka S, Gronwald J, Kowalska E, Haus O, Grzybowska E, Stawicka M, Swiec M, Urbanski K, Niepsuj S, Wasko B, Gozdz S, Wandzel P, Szczylik C, Surdyka D, Rozmiarek A, Zambrano O, Posmyk M, Narod SA, Lubinski J. A common variant of CDKN2A (p16) predisposes to breast cancer. J Med Genet 2005; 42: 763-765.

12. Dowsett M, Cuzick J, Wale C, Howell T, Houghton J, Baum M. Retrospective analysis of time to recurrence in the ATAC trial according to hormone receptor status: an hypothesisgenerating study. J Clin Oncol 2005; 23: 7512-7517.

13. Eisen A, Lubinski J, Klijn J, Moller P, Lynch HT, Offit K, Weber B, Rebbeck T, Neuhausen SL, Ghadirian P, Foulkes WD, Gershoni-Baruch R, Friedman E, Rennert G, Wagner T, Isaacs C, 
Kim-Sing C, Ainsworth P, Sun P, Narod SA. Breast cancer risk following bilateral oophorectorny in BRCA1 and BRCA2 mutation carriers: An international case-control study. J Clin Oncol 2005; 23: 7491-7496.

14. Eliassen AH, Colditz GA, Rosner B, Willett WC, Hankinson SE. Serum lipids, lipid-lowering drugs, and the risk of breast cancer. Arch Intern Med 2005; 165: 2264-2271.

15. Espinosa E, Vara JAF, Redondo A, Sanchez JJ, Hardisson D, Zamora P, Pastrana FG, Cejas P, Martinez B, Suarez A, Calero F, Baron MG. Breast cancer prognosis determined by gene expression profiling: a quantitative reverse transcriptase polymerase chain reaction study. J Clin Oncol 2005; 23: 7278-7285.

16. Farabegoli F, Ceccarelli C, Santini D, Taffurelli M. Suppressor of cytokine signalling 2 (SOCS-2) expression in breast carcinoma. J Clin Pathol 2005; 58: 1046-1050.

17. Folgueira M, Carraro DM, Brentani H, Patra DFD, Barbosa EM, Netto MM, Caldeira JRF, Katayama MLH, Soares FA, Oliveira CT, Reis LFL, Kaiano JHL, Camargo LP, Vencio RZN, Snitcovsky IML, Makdissi FBA, Silva P, Goes J, Brentani MM. Gene expression profile associated with response to doxorubicin-based therapy in breast cancer. Clin Cancer Res 2005; 11: 7434-7443.

18. Garvin S, Nilsson UW, Dabrosin C. Effects of oestradiol and tamoxifen on VEGF, soluble VEGFR-1, and VEGFR-2 in breast cancer and endothelial cells. $\mathrm{Br} J$ Cancer 2005; 93: 1005-1010.

19. Gianni L, Zambetti M, Clark K, Baker J, Cronin M, Wu J, Mariani G, Rodriguez J, Carcangiu M, Watson D, Valagussa P, Rouzier R, Symmans WF, Ross JS, Hortobagyi GN, Pusztai L, Shak S. Gene expression profiles in paraffin-embedded core biopsy tissue predict response to chemotherapy in women with locally advanced breast cancer. J Clin Oncol 2005; 23: 7265-7277.

20. Gonzalez-Angulo AM, McGuire SE, Buchholz TA, Tucker SL, Kuerer HM, Rouzier R, Kau SW, Huang EH, Morandi P, Ocana A, Cristofanilli M, Valero V, Buzdar AU, Hortobagyi GN. Factors predictive of distant metastases in patients with breast cancer who have a pathologic complete response after neoadjuvant chemotherapy. J Clin Oncol 2005; 23: 7098-7104.

21. Grimm SL, Contreras A, Barcellos-Hoff $M H$, Rosen JM. Cell cycle defects contribute to a block in hormone-induced mammary gland proliferation in CCAAT/enhancer-binding protein (C/EBP beta)-null mice. J Biol Chem 2005; 280: 36301-36309.
22. Helguero LA, Faulds MH, Gustafsson JA, Haldosen LA. Estrogen receptors alfa (ER alpha) and beta (ER beta) differentially regulate proliferation and apoptosis of the normal murine mammary epithelial cell line HC11. Oncogene 2005; 24: 6605-6616.

23. Honrado E, Osorio A, Palacios J, Milne RL, Sanchez L, Diez O, Cazorla A, Syrjakoski K, Huntsman D, Heikkila N, Lerma E, Kallioniemi A, Rivas C, Foulkes WD, Nevanlinna H, Benitez J. Immunohistochemical expression of DNA repair proteins in familial breast cancer differentiate BRCA2-associated tumors. J Clin Oncol 2005; 23: 7503-7511.

24. Hopper JL, Hayes VM, Spurdle AB, ChenevixTrench $G$, Jenkins MA, Milne RL, Dite GS, Tesoriero AA, McCredie MRE, Giles GG, Southey MC. A protein-truncating mutation in CYP17A1 in three sisters with early-onset breast cancer. Hum Mutat 2005; 26: 298-302.

25. Hui L, Rodrik V, Pielak RM, Knirr S, Zheng Y, Foster DA. mTOR-dependent suppression of protein phosphatase $2 \mathrm{~A}$ is critical for phospholipase $D$ survival signals in human breast cancer cells. J Biol Chem 2005; 280: 35829-35835.

26. Johnson N, Fletcher O, Naceur-Lombardelli C, Silva ID, Ashworth A, Peto J. Interaction between CHEK2*1100delC and other low-penetrance breast-cancer susceptibility genes: a familial study. Lancet 2005; 366: 1554-1557.

27. Khalili P, Arakelian A, Chen GP, Singh G, Rabbani SA. Effect of Herceptin on the development and progression of skeletal metastases in a xenograft model of human breast cancer. Oncogene 2005; 24: 6657-6666.

28. Kirkegaard T, Witton CJ, McGlynn LM, Tovey SM, Dunne B, Lyon A, Bartlett JMS. AKT activation predicts outcome in breast cancer patients treated with tamoxifen. J Pathol 2005; 207: 139-146.

29. Kronblad A, Hedenfalk I, Nilsson E, Pahlmann S, Landberg G. ERK1/2 inhibition increases antiestrogen treatment efficacy by interfering with hypoxia-induced downregulation of ER alpha: a combination therapy potentially targeting hypoxic and dormant tumor cells. Oncogene 2005; 24: 6835-6841.

30. Laakso $\mathrm{M}$, Loman $\mathrm{N}$, Borg A, Isola J. Cytokeratin 5/14-positive breast cancer: true basal phenotype confined to BRCA1 tumors. Mod Pathol 2005; 18: 1321-1328.

31. Lund CV, Popkov M, Magnenat L, Barbas CF. Zinc finger transcription factors designed for bispecific coregulation of ErbB2 and ErbB3 receptors: insights into ErbB receptor biology. Mol Cell Biol 2005; 25: 9082-9091. 
32. Magnusson CMK, Roddam AW, Pike MC, Chilvers C, Crossley B, Hermon C, McPherson K, Peto J, Vessey M, Beral V. Body fatness and physical activity at young ages and the risk of breast cancer in premenopausal women. $\mathrm{Br} J$ Cancer 2005; 93: 817-824.

33. Martin NL, Saba-El-Leil MK, Sadekova S, Meloche S, Sauvageau G. EN2 is a candidate oncogene in human breast cancer. Oncogene 2005; 24: 6890-6901.

34. Martin RM, Middleton N, Gunnell D, Owen CG, Smith GD. Breast-feeding and cancer: The Boyd Orr cohort and a systematic review with meta-analysis. J Natl Cancer Inst 2005; 97: 1446-1457.

35. Maskarinec G, Pagano I, Lurie G, Wilkens LR, Kolonel LN. Mammographic density and breast cancer risk - The multiethnic cohort study. $A m \mathrm{~J}$ Epidemiol 2005; 162: 743-752.

36. Millikan RC, Player JS, deCotret AR, Tse CK, Keku T. Polymorphisms in DNA repair genes, medical exposure to ionizing radiation, and breast cancer risk. Cancer Epidemiol Biomar Prevent 2005; 14: 2326-2334.

37. Nanda R, Schumm LP, Cummings $S$, Fackenthal JD, Sveen L, Ademuyiwa F, Cobleigh $M$, Esserman L, Lindor NM, Neuhausen SL, Olopade OI. Genetic testing in an ethnically diverse cohort of high-risk women a comparative analysis of BRCA1 and BRCA2 mutations in American families of European and African ancestry. JAMA 2005; 294: 1925-1933.

38. Noruzinia M, Coupier I, Pujol P. Is BRCA1/ BRCA2-related breast carcinogenesis estrogen dependent? Cancer 2005; 104: 1567-1574.

39. Poola I, Fuqua SAW, De Witty RL, Abraham J, Marshallack J, Liu AY. Estrogen receptor alphanegative breast cancer tissues express significant levels of estrogen-independent transcription factors, ER beta 1 and ER beta 5: Potential molecular targets for chernoprevention. Clin Cancer Res 2005; 11: 7579-7585.

40. Queen MM, Ryan RE, Holzer RG, Keller-Peck CR, Jorcyk CL. Breast cancer cells stimulate neutrophils to produce oncostatin M: Potential implications for tumor progression. Cancer Res 2005; 65: 8896-8904.

41. Rakha EA, Boyce RWG, Abd El-Rehim D, Kurien T, Green AR, Paish EC, Robertson JFR, Ellis IO. Expression of mucins (MUC1, MUC2,
MUC3, MUC4, MUC5AC and MUC6) and their prognostic significance in human breast cancer. Mod Pathol 2005; 18: 1295-1304.

42. Sieuwerts AM, Meijer-van Gelder ME, Timmermans M, Trapman A, Garcia RR, Arnold M, Goedheer AJW, Portengen H, Klijn JGM, Foekens JA. How ADAM-9 and ADAM-11 differentially from estrogen receptor predict response to tamoxifen treatment in patients with recurrent breast cancer: a retrospective study. Clin Cancer Res 2005; 11: 7311-7321.

43. Tynan JA, Wen F, Muller WJ, Oshima RG. Ets2dependent microenvironmental support of mouse mammary tumors. Oncogene 2005; 24: 6870-6876.

44. Urruticoechea A, Smith IE, Dowsett M. Proliferation marker Ki-67 in early breast cancer. $J$ Clin Oncol 2005; 23: 7212-7220.

45. Wang XJ, Li N, Li HZ, Liu B, Qiu JM, Chen TY, Cao XT. Silencing of human phosphatidylethanolamine-binding protein 4 sensitizes breast cancer cells to tumor necrosis factor-alpha-induced apoptosis and cell growth arrest. Clin Cancer Res 2005; 11: 7545-7553.

46. Weigelt B, Hu ZY, He XP, Livasy C, Carey LA, Ewend MG, Glas AM, Perou CM, van't Veer LJ. Molecular portraits and 70-gene prognosis signature are preserved throughout the metastatic process of breast cancer. Cancer Res 2005; 65: 9155-9158.

47. Weigelt B, Wessels LFA, Bosma AJ, Glas AM, Nuyten DSA, He YD, Dai H, Peterse JL, van't Veer LJ. No common denominator for breast cancer lymph node metastasis. $\mathrm{Br} J$ Cancer 2005; 93: 924-932.

48. Weil RJ, Palmieri DC, Bronder JL, Stark AM, Steeg PS. Breast cancer metastasis to the central nervous system. Am J Pathol 2005; 167: 913-920.

49. Xu Y, Yao LH, Ouyang T, Li JF, Wang TF, Fan ZQ, Lin BY, Lu YY, Xie YT. p53 codon 72 polymorphism predicts the pathologic response to neoadjuvant chemotherapy in patients with breast cancer. Clin Cancer Res 2005; 11: 7328-7333.

Prepared by

R. Sutherland, J. Scorer Cancer Research Program Garvan Institute of Medical Research Darlinghurst, NSW, Australia 